\title{
Linking Luxury Brand Perceived Value, Brand Attachment, and Purchase Intention: The Role of Consumer Vanity
}

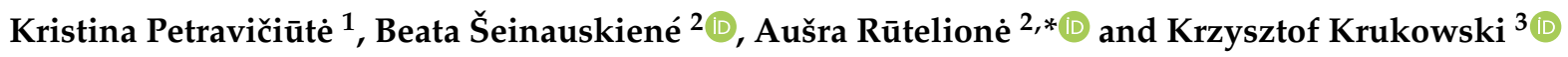 \\ 1 Tandemo Sprendimai, JSC, K. Donelaičio g. 60, 44248 Kaunas, Lithuania; kristina@tandemum.lt \\ 2 School of Economics and Business, Kaunas University of Technology, 44239 Kaunas, Lithuania; \\ beata.seinauskiene@ktu.lt \\ 3 Institute of Management and Quality Sciences, University of Warmia and Mazury in Olsztyn, \\ 10-719 Olsztyn, Poland; kkruk@uwm.edu.pl \\ * Correspondence: ausra.rutelione@ktu.lt
}

check for

updates

Citation: Petravičiūtè, K.;

Šeinauskiené, B.; Rūtelionè, A.;

Krukowski, K. Linking Luxury Brand

Perceived Value, Brand Attachment, and Purchase Intention: The Role of Consumer Vanity. Sustainability 2021, 13, 6912. https://doi.org/10.3390/ su13126912

Academic Editors: Sebastian Kot and Beata Slusarczyk

Received: 26 April 2021

Accepted: 15 June 2021

Published: 18 June 2021

Publisher's Note: MDPI stays neutral with regard to jurisdictional claims in published maps and institutional affiliations.

Copyright: (c) 2021 by the authors. Licensee MDPI, Basel, Switzerland. This article is an open access article distributed under the terms and conditions of the Creative Commons Attribution (CC BY) license (https:// creativecommons.org/licenses/by/ $4.0 /)$.

\begin{abstract}
The current study adds to the literature on the indirect effect of luxury brand perceived value on purchase intention via the brand attachment under the boundary conditions of consumer vanity. The authors employed a quantitative method approach, conducting an online survey with 508 respondents in Lithuania. Empirical research analysis reveals that the greater the perceived value of a luxury brand, the greater the consumer purchase intention. The latter is most strongly affected by the luxury brand perceived functional value. The study demonstrates that the greater the luxury brand perceived value among consumers, the greater their brand attachment, which in turn leads to a greater purchase intention. As there is a positive emotional relationship between a luxury brand and the consumer, the consumer's purchase intention is also affected by the luxury brand perceived symbolic value, i.e., the capacity of the brand to communicate the consumer's success, leadership, and power. Consumer vanity was not statistically significant to the nature of the relationship between luxury brand perceived value, brand attachment, and purchase intention. Luxury car marketers may benefit by focusing on the social and symbolic value of luxury car brand value in communication with brand-attached consumers in Lithuania.
\end{abstract}

Keywords: luxury brand perceived value; brand attachment; purchase intention; consumer vanity

\section{Introduction}

In recent years, researchers have been increasingly attentive to topics of luxury, luxury goods, and luxury brands. One of the factors encouraging such interest is the growth of the global luxury market. During the past twenty years, the total number of this market's consumers has tripled worldwide [1]. It has been estimated that this market will grow annually by $5.63 \%$ in Lithuania [2]. Nevertheless, the Covid-19 crisis has hit and changed the luxury and fashion industry substantially [3] and accelerated a channel shift to ecommerce as well as an emphasis on innovations related to sustainability and circular design [4]. Due to the issues caused by the pandemic, marketing specialists have had difficulty ensuring a sufficient perceived value of luxury brands among consumers [5].

According to Kapferer and Bastien, the concept of luxury is attractive and fashionable, so even mass-production brands try to make their goods and the consumer experience reflect a sense of luxuriousness [6]. As a result, it becomes difficult for the consumer to understand what truly is a luxury good or a luxury brand [6]. In addition, despite the attention that researchers have paid to the study of luxury brands, it remains unclear how these brands can be brought to the market most efficiently [7,8], whereas the concept of 'luxury' does not have a clear definition [9-12] and researchers agree on little of what it includes [8,11,13-15].

Scientific literature analysis reveals that the direct relationship between luxury brand perceived value and purchase intention has already been widely considered [15-19]. Never- 
theless, research results indicate that separate dimensions of luxury brand perceived value differently affect (or do not affect) purchase intention [15-17,19]. The inconsistent findings of the relationship between individual dimensions of luxury brand perceived value and purchase intention suppose a need for research into the underlying mechanisms and the boundary conditions of the abovementioned relationship. Brand attachment was found to be a predictor of consumer purchase intention $[17,20-23]$. This relationship suggests that brand attachment may potentially explain the relationship between luxury brand perceived value and purchase intention. Moreover, research shows that consumer vanity, although considered only fragmentally in the context being discussed, has an effect on the relationship between luxury brand perceived value and purchase intention $[16,17]$. We address the abovementioned research gap by exploring the effect of luxury brand perceived value on brand attachment and purchase intention, considering the moderating role of consumer vanity. Thus, this study aims to to uncover the effect of luxury brand perceived value on brand attachment and purchase intention in the context of consumer vanity. Our key research questions are: how does luxury brand perceived value affect brand attachment and, in turn, purchase intention, and how does consumer vanity affect the nature of the relationship between luxury brand perceived value, brand attachment, and purchase intention?

The current study makes several contributions to the field of luxury brand perceived value and brand attachment. It builds on previous research by arguing that brand attachment acts as a mediator, transmitting the effect of luxury brand perceived value on purchase intentions. Furthermore, this study investigates the disentangled effects of individual dimensions of luxury brand perceived value on brand attachment and purchase intention, in such a manner revealing a more refined picture of the effects of each individual dimension. Finally, the study raises the question of whether consumer vanity influences the nature of the relationship between luxury brand perceived value and brand attachment and luxury brand perceived value and purchase intention.

\section{Theoretical Background and Hypothesis Development}

\subsection{Theoretical Perspective on Luxury Consumption}

The transformative nature of luxury meanings prevents agreement on a fixed definition [24]. Most commonly, luxury is expressed through excellence, creativity, and exclusivity, with the modern approach indicating that even one of these conditions is sufficient to represent luxury driven by brands [25]. Luxury and conspicuousness are inextricably linked, despite the fact that luxury means different things to different people. Branddisplayed luxury communicates symbolic meanings to others and helps to signal status, distinctiveness, power, and wealth. Therefore, the conventional meaning of luxury is perceived as socially oriented and rooted in self-interest [26]. Given the above, it is plausible to suggest that consumers value luxury for its properties in conveying the externally oriented meanings and in obtaining desirable self-oriented transformations. Wiedmann et al. [27] proposed the theoretical framework that defines luxury "as the highest level of prestigious brands encompassing several physical and psychological values" [27] (p. 1).

The luxury phenomenon has received a vast amount of scientific attention across different disciplines. For example, a bibliometric citation review conducted by [28] identified ten different luxury research perspectives that have evolved over time-luxury consumption as a social phenomenon, luxury goods as a status signal, luxury culture and meaning, self-concept and relationships, and brand equity to name but a few. The consumer perspective dominates in the domain of luxury research. Recent developments in the field revealed that luxury consumption antecedents range from biological and sociopsychological to structural, such as income inequality [29]. Moreover, the growing body of luxury culture and meaning research shows that luxury has become a fluid concept. Luxuriousness may imply meanings that far depart from the conventional understanding of luxury consumption as exclusivity-driven status consumption [30]. Both material objects and very internally oriented and subjective consumer experiences can be symbolically 
charged with aspirational value [31]. As a result, luxury consumption takes on many different forms and can be seen as uniquely defined and constructed. Self-determination theory [32] is the dominant conceptual foundation in luxury research, positing that luxury consumption is motivated by both intrinsic (self-identity) and extrinsic (aspiration for status, external rewards) motives. Consumers aspire to personal or interpersonal values derived from luxury consumption [8]. Nonetheless, the desire for status is regarded as the primary motivator driving luxury consumption.

Intrinsic and extrinsic motivation have many parallels with the self-concept literature stream [33]. Luxury brands whose user and usage imagery are congruent with the consumer's self-concept are more positively approached by consumers [34]. Similarly, Malär et al. [35] found, however not within the luxury context, that actual self-congruence boosts emotional brand attachment. The explanation for the abovementioned relationship is built on the self-verification theory, which suggests that people are prone to behaving consistently with their self-concept. Consequently, it is logical to derive that the same relationship pattern should be plausible in the luxury brand domain. Luxury brands promise value, which may serve as a source of identity and self-expression, consequently strengthening the consumer-brand connection. While the actual self-congruence-related brand attachment manifests itself as the intrinsic motivation for luxury consumption, the ideal-self congruence is attributable to the extrinsic set of motives. The value derived from the luxury brand helps to build the aspirational self through compensation for selfdiscrepancies and developing a desirable identity. The ideal self-congruence was also found to be linked to heightened attachment to the luxury brand [21]. Thus, the luxury brand provides value, which can be used as a resource for constructing the ideal self. However, recent studies assume that self-congruence motives may be in tension. For example, the symbolic value of a luxury brand may be at odds with the consumer's feeling of self-authenticity, which is more in line with the true or actual self, therefore resulting in a higher degree of self-discrepancy between the real and ideal self [36].

The current study's hypotheses were theoretically inferred from the self-congruence and attachment literature in line with the above reasoning. The luxury brand promises value, which may be used to sustain the actual self-concept or build the ideal self, which in turn improves the brand-self connection and positively affects behavioral intentions. Luxury brands pose desirable properties that provide benefits or resources for consumers in obtaining status, uniqueness, and other types of other or self-directed individual transformations. Luxury-brand-associated values function as the conveyors of identity, facilitating the creation of the desired self. The power of the luxury brand to enhance the ideal self or social self-concept further positively contributes to the consumer-brand relationship, translating into positive behavioral outcomes.

\subsection{Effect of Luxury Brand Perceived Value on Purchase Intention}

All three terms-luxury, luxury brands, and luxury goods—share similar definitions and conceptually overlap with one another. The classification of a product or brand as luxurious vs. ordinary usually depends on the consumer's perception of the value offered by the product or brand in question. Ko, Costello, and Taylor state that there is still no widely accepted definition of 'luxury brand' [37]. The authors emphasize that consumers perceive a luxury brand to be of high quality, offering authentic value through desired benefits (both functional and emotional), having a prestigious market image, being worthy of the highest price, and having a deep connection with the consumer. Luxury brand perceived value is a multidimensional construct that includes functional, experiential, and symbolic values $[8,11,13-15,38]$. The dimension of perceived functional value indicates the function and physical characteristics that a brand possesses. Perceived experiential value defines what a brand means to the individual, and perceived symbolic value refers to what the brand signifies to others [38].

A number of scientific studies have uncovered a link between luxury brand perceived value and consumer purchase intention $[11,15-17,19]$. Consumers who perceive the value 
that they expect and desire from the particular brand are ready to purchase and re-buy brands, recommend the brand to other consumers, and pay the highest price even if there are attractive competitive alternatives or cheap counterfeits on the market. For this reason, consumer subjective expectations and the perceived luxury brand value are significant causal factors in luxury consumption behavior [11].

Researchers have found that luxury brand perceived functional and experiential value have positive effects on luxury brand purchase intention [16,17]. Therefore, luxury brands must provide high quality and craftsmanship [16]. Research also shows that separate dimensions of luxury brand perceived value affect (or do not affect) consumer purchase intention differently $[15-17,19]$, therefore presupposing the existence of an underlying causal mechanism. Choo et al. have found a strong relationship between the perceived functional value of a Korean luxury brand and consumer behavioral intention in the case of luxury fashion brands [16]. It is noted that, in order to attract new consumers, luxury brands should be characterized by excellent quality. In another study, Cheah et al. found that a higher perceived luxury brand functional and experiential value by Australian consumers leads to a higher purchase intention; however, the perceived luxury brand symbolic value was negatively correlated with the willingness to buy a luxury brand [17].

The previous research shows that the perceived luxury brand value plays an important role in consumer purchase intention, but the effect of this value may vary across countries and cultures. Taking into account the provided arguments, we hypothesize that:

Hypothesis 1a ( H1a). Luxury brand perceived value has a positive effect on purchase intention.

Hypothesis 1b ( H1b). Luxury brand perceived functional value has a positive effect on purchase intention.

Hypothesis 1c ( H1c). Luxury brandperceived experiential value has a positive effect on purchase intention.

Hypothesis 1d ( H1d). Luxury brand perceived symbolic value has a positive effect on purchase intention.

\subsection{Effect of Brand Attachment on Purchase Intention}

Brand attachment is defined as an emotional connection between the consumer and a particular brand and reflects their feelings about the brand [39,40]. Many researchers [17,21,22,39,41,42] rely on Park et al.'s conceptual structure of brand attachment that consists of two components: brand prominence and brand-self connection [40]. However, different definitions of brand prominence can be found in the literature. For example, Han et al. refer to brand prominence as the ability of a brand to be recognized by others through visible markings and therefore signifies the degree of the brand's conspicuousness [43]. The definition used in the current study is based on the conceptualization proposed by Park et al. [40], where brand prominence refers to "the salience of the cognitive and affective bonds that connects the brand to the self" [40] (p. 2). Brand-self connection refers to the aspect of brand attachment that manifests as a feeling of oneness with the brand [40]. Consequently, Park et al. [40] state that brand attachment develops as a result of recognizing a brand as part of one's self-concept and because of the instrumental value brands can offer.

Empirical research by Kaufmann et al., Vercueil, $\mathrm{Ku}$ and Lin, Cheah et al., and Saeed et al. shows the existence of a relationship between brand attachment and consumer purchase intention [17,20-23]. Strong brand attachment leads to consumer loyalty $[20,40-42,44,45]$, a competitive advantage in the case of alternatives [40,45], lower consumer sensitivity to price [41,45], milder consequences in the case of brand failure [41,45], consumer resilience to change [41], favorable verbal recommendations, and a desire to maintain a relationship with the brand [45].

Saeed et al. emphasize that the intention to purchase a product determines why the consumer buys the brand at a certain time and under certain conditions [20]. Based on the results of Porter's research, a consumer will not want to buy the same brand again if the said consumer's attachment to the brand is weak [46]. Thus, brand attachment is expected 
to have a positive impact on the consumer's intention to purchase. The results show that there is a positive relationship between the consumer's attachment to the brand and their intention to buy it.

Cheah et al. note that brand prominence has a positive effect on consumer purchase intention towards luxury brands [17], while empirical research by Kaufmann et al. and Ku and Lin confirm this positive effect of the aforementioned two components on consumer purchase intention towards luxury brands [21,22]. As pointed out by Hung et al. and Taghipourian and Bakhsh, a feeling of emotional connection drives consumer brand attachment; as a result, a brand becomes extremely important to the consumer and strengthens their purchase intention [16,42]. Kaufmann et al. found that brand love, which is conceptually related to brand attachment, likewise has a positive effect on consumer purchase intention [21]. $\mathrm{Ku}$ and Lin emphasize that brand attachment helps to predict consumer behavior, including actual purchasing behavior [22]. The results of their study indicate that brand prominence affects consumer purchase intention more than brand-self connection.

According to Louis and Lombart, brand attachment is a long-term and terminal outcome of the brand-consumer relationship that can affect current behavior and future purchase intentions [47]. Given the above, following hypotheses are proposed:

Hypothesis 2a ( H2a). Brand attachment has a positive effect on purchase intention.

Hypothesis $\mathbf{2 b}$ ( $\mathbf{H} 2 \mathbf{b})$. Brand prominence has a positive effect on purchase intention.

Hypothesis 2c ( $\mathbf{H 2 c})$. Brand-self connection has a positive effect on purchase intention.

\subsection{Relationship between Luxury Brand Perceived Value, Brand Attachment, and Purchase Intention}

Research that links brand attachment and luxury brand perceived value has been largely ignored. Park et al. indicate that brand attachment occurs when a brand takes root in the consumer's subconscious, creating a connection between the brand and the consumer's self-concept [40]. The authors emphasize that the link between perceived brand value and brand attachment is obvious, but they do not base it on empirical evidence. Cheah et al. have analyzed the links between functional, experiential, and symbolic luxury brand values and brand prominence [17]. A positive relationship between luxury brand value and brand prominence was explained by the fact that brand prominence denotes brand visibility, which is vital in the consumption of luxury brands, because the primary motivation is to demonstrate those brands to important others-to use brands conspicuously [48]. This conspicuous consumption could be explained by the uniqueness theory, which asserts that consumers attempt to differentiate themselves from others through tangible goods $[49,50]$. Based on Han, Nunes, and Drèze, the authors emphasize that the perceived functional luxury brand value could positively affect brand prominence [48]. Similarly, the perceived experiential brand value can elicit a cognitive and behavioral response from the consumer [38], and therefore could potentially have a positive effect on brand prominence. Researchers point out that consumers often try to associate their self-concept with brand prestige, exclusivity, and fashion; thus, symbolic benefits are quite important for socially visible brands [51]. This supports the likely effect of perceived luxury brand symbolic value on brand prominence [17]. Furthermore, the authors indicate that the perceived symbolic luxury brand value has a negative effect on brand prominence in the case of prominent brands, but a positive link has been found in the case of more obscure brands. Nevertheless, the authors do not provide a plausible explanation for such results. Summarizing the results of recent research on the relationship between luxury brand perceived value and brand attachment, it appears that research is sparse, and results vary depending on the luxury brand and the symbolic value it conveys $[17,22]$. Nevertheless, a literature review provides a theoretical rationale for suggesting that brand attachment may potentially mediate the luxury brand perceived value and purchase intention relationship. Empirical evidence supports the claim that both brand attachment [17,20-23] and luxury 
brand perceived value have a positive effect on consumer purchase intention [11,15-17,19]. Furthermore, brand satisfaction is suggested to be an antecedent to luxury brand attachment and shows a positive association with the latter [52]. Brand satisfaction stems from the anticipated or experienced perceived value [53]. Moreover, consumers form strong bonds with brands when brands provide hedonic, symbolic, or functional resources that allow consumers to gratify, enrich, or enable themselves [45]. Recent studies empirically support such a relationship pattern (however, not within the context of luxury brands). For example, Liu et al. found that functional, symbolic, and hedonic values determine brand attachment within the context of the hotel industry [52]. Therefore, based on the above arguments, we assume that brand attachment may potentially explain the relationship between luxury brand perceived value and purchase intention. Recent studies demonstrate a high degree of interest in the relationship between luxury brand perceived value and purchase intention $[17,22]$. However, these relationships differ in strength and nature in different luxury brand cases. The literature analysis suggests that luxury brand perceived value may have an indirect effect on purchase intention, i.e., via brand attachment. The higher the luxury brand perceived value, the greater the brand attachment, which in turn increases purchase intention. Therefore, we hypothesize that:

Hypothesis 3a ( H3a). Brand attachment mediates the relationship between luxury brand perceived value and purchase intention in such a way that luxury brand perceived value has a positive effect on brand attachment, which, in turn, has a positive effect on purchase intention.

Hypothesis $\mathbf{3 b} \mathbf{(} \mathbf{H} 3 \mathbf{b})$. Brand prominence mediates the relationship between luxury brand perceived functional value and purchase intention in such a way that luxury brand perceived functional value has a positive effect on brand prominence, which, in turn, has a positive effect on purchase intention.

Hypothesis 3c ( H3c). Brand prominence mediates the relationship between luxury brand perceived experiential value and purchase intention in such a way that luxury brand perceived experiential value has a positive effect on brand prominence, which, in turn, has a positive effect on purchase intention.

Hypothesis 3d ( H3d). Brand prominence mediates the relationship between luxury brand perceived symbolic value and purchase intention in such a way that luxury brand perceived symbolic value has a positive effect on brand prominence, which, in turn, has a positive effect on purchase intention.

Hypothesis 3e( H3e). Brand-self connection mediates the relationship between luxury brand perceived functional value and purchase intention in such a way that luxury brand perceived functional value has a positive effect on brand-self connection, which, in turn, has a positive effect on purchase intention.

Hypothesis $3 \mathbf{f}$ ( $\mathbf{H 3} \mathbf{f})$. Brand-self connection mediates the relationship between luxury brand perceived experiential value and purchase intention in such a way that luxury brand perceived experiential value has a positive effect on brand-self connection, which, in turn, has a positive effect on purchase intention.

Hypothesis $3 \mathbf{g} \mathbf{~ ( ~ H 3 g ) . ~ B r a n d - s e l f ~ c o n n e c t i o n ~ m e d i a t e s ~ t h e ~ r e l a t i o n s h i p ~ b e t w e e n ~ l u x u r y ~ b r a n d ~}$ perceived symbolic value and purchase intention in such a way that luxury brand perceived symbolic value has a positive effect on brand-self connection, which, in turn, has a positive effect on purchase intention. 


\subsection{Effect of Consumer Vanity on the Relationship between Luxury Brand Perceived Value and Brand Attachment}

Jun, Liang, Qiong, and Jian describe vanity as a psychological trait that indicates a desire to attribute to oneself an honor that one does not actually have or cannot have but whose possession one nonetheless attempts to demonstrate through words and deeds [54]. In the consumer behavior literature, consumer vanity includes four distinct aspects: (1) physical concern; (2) a physical view; (3) an achievement concern; and (4) an achievement view [55]. The first and second dimensions include physical vanity, and the third and fourth relate to the vanity of achievement [55-57]. Netemeyer et al. define physical vanity as an excessive concern for and/or a positive and potentially exaggerated view of one's physical appearance [55]. Achievement vanity is defined as excessive concern for and/or a positive and potentially exaggerated attitude towards one's personal achievements [55].

There is no research analyzing the moderating effect of consumer vanity on the relationship between luxury brand perceived value and brand attachment. Workman and Lee found that consumer vanity can affect consumer behavior in relation to brand selection [58]. According to the abovementioned authors, consumers with expressed physical appearance and achievement vanity choose goods based on their brand and give priority to prestigious brands since these are related to wealth and social status. Workman and Lee note that all four vanity dimensions are related to brand sensitivity and the brandbased selection of goods [58]. Given the preceding arguments, it is reasonable to assume that consumers who score highly on vanity will place a higher value on luxury brands and be more susceptible to brand attachment. Consumers who exhibit a high level of vanity are concerned about how others perceive them, so they are more likely to rely on luxury brand value to signal their desirable self. Because luxury brands are valued for their ability to convey symbolic meanings, they would be especially valuable to vanityoriented consumers in terms of providing resources that help demonstrate and sustain the consumer's desired self-concept. Thus, we hypothesize that:

Hypothesis 4 ( H4). Consumer vanity moderates the relationship between luxury brand perceived value and brand attachment in such a way that as the level of consumer vanity increases, the positive relationship between luxury brand perceived value and brand attachment strengthens.

\subsection{Effect of Consumer Vanity on the Relationship between Luxury Brand Perceived Value and Purchase Intention}

According to Workman and Lee, consumer vanity has a significant impact on consumer behavior [58]. According to the authors, consumers with physical and achievement vanity choose goods according to the brand and prefer prestigious ones because they are associated with wealth and social status. Physical and achievement vanity affect consumer sensitivity to the brand and the choice of goods based on the brand. Thus, vanity influences consumer decisions, especially regarding brands [58].

Research conducted by Hung et al. and Cheah et al. shows that consumer vanity may moderate the relationship between luxury brand perceived value and purchase intention $[16,17]$. The results of the study by Hung et al. indicate that only achievement vanity has a positive effect on the relationship between brand perceived value and intention to purchase luxury handbags. These results are explained by the fact that perceived luxury brand value has a greater symbolic meaning to those who seek status through achievement than to those who emphasize physical appearance.

Both physical appearance and achievement vanity strengthen the relationship between luxury brand perceived value and purchase intention in cases of well-known luxury brands [17]. For persons who aim for a higher status via luxury brands that carry high symbolic value, achievement vanity (concern about individual achievements and an attitude towards the dimension of individual achievements) can strengthen the positive relationship between luxury brand perceived value and purchase intention [16]. In addition, individuals who seek physical attractiveness and recognition by others tend to purchase luxury brands 
that emphasize value and are well-known [17]. Based on the abovementioned arguments, a further hypothesis is suggested:

Hypothesis $\mathbf{5}$ ( H5). Consumer vanity moderates the relationship between luxury brand perceived value and purchase intention in such a way that as the level of consumer vanity increases, the positive relationship between luxury brand perceived value and purchase intention strengthens.

Figure 1 shows the conceptual modelthat shows the links between luxury brand perceived value, brand attachment, purchase intention, and consumer vanity.

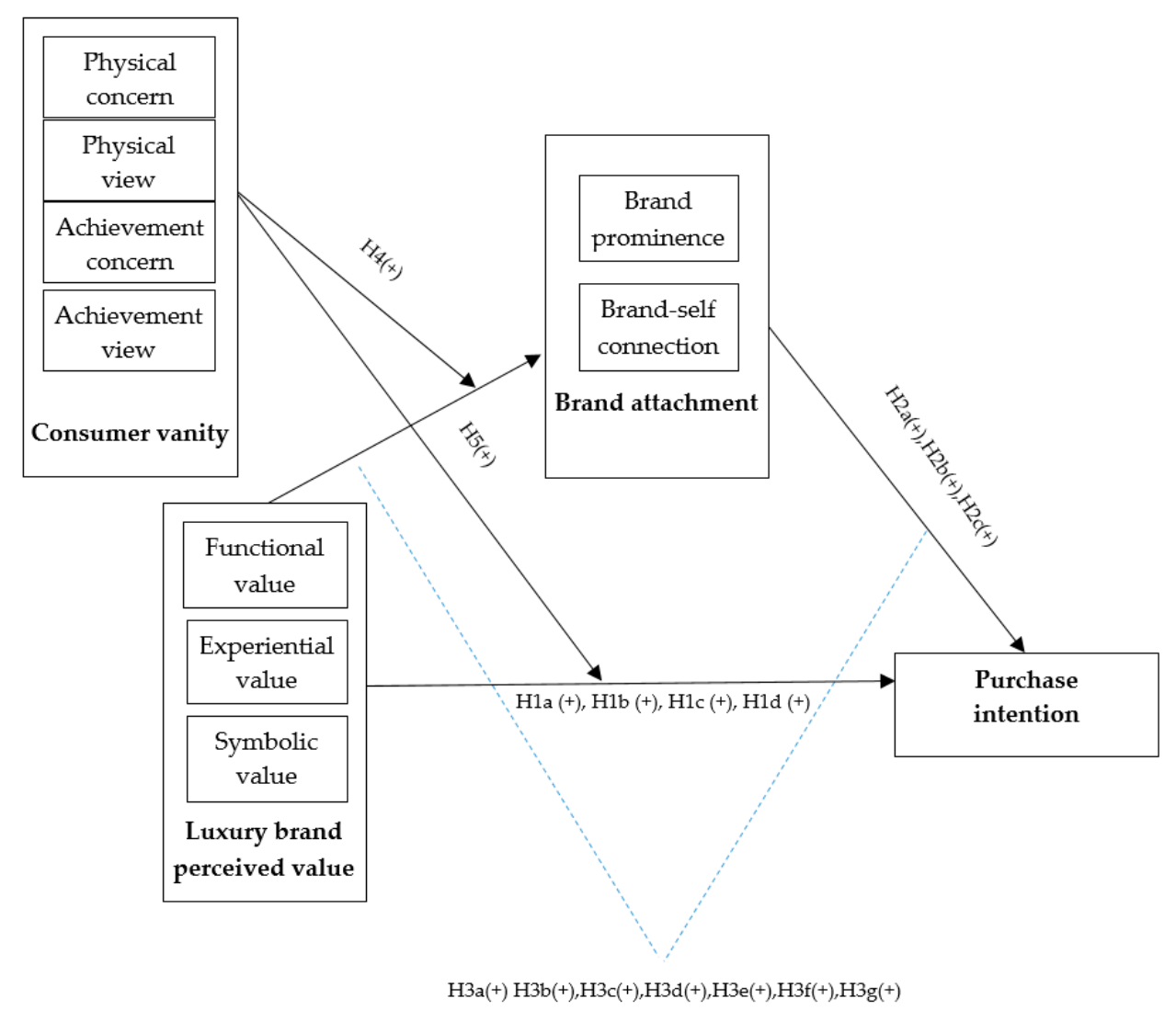

Figure 1. Conceptual model.

\section{Materials and Methods}

\subsection{Research Objective, Method, and Data}

This empirical study aims is to identify the links between luxury brand perceived value, brand attachment, purchase intention, and consumer vanity in the case of luxury cars. For this purpose, the online survey method was employed. The questionnaire was distributed using the non-random convenience sampling method. The use of this method is justified if the objective of the research is only to test theoretical assumptions about relationships between luxury brand perceived value, brand attachment, purchase intention, and consumer vanity [59]. Moreover, the selection of this sampling method was determined by the lack of access to a list of the population being studied. A non-statistical comparative sample size determination method was chosen for the study [60]. Thirteen similar studies analyzing the relationships between at least two of the constructs under study were identified $[15-17,19,22,61,62]$. The analysis shows that the sample size for this study should be considered to be at least equal to the established mean, which is 476 respondents. Moreover, all investigated previous studies used a survey method. The link to the survey was advertised through LinkedIn and Facebook social networks, writing personal messages to existing contacts, placing the questionnaire in specialized groups, 
and purchasing online advertising in 2019. These survey dissemination methods were chosen due to their effectiveness in achieving the maximum number of respondents in a minimum period of time.

A total of 512 participants completed the questionnaire, but the responses of 4 respondents were excluded based on the age of these respondents, which was less than 18 years. The final sample was composed of 508 (70.9\% male and 29.1\% female) individuals over 18 years old living in Lithuania (mean age $=37$ years). The age ranges from 19 to 66 years with a mean age of 37 years. The mean age (36.7) is close to the median (36), which indicates that the values were distributed close to a normal distribution. The symmetric age distribution is also confirmed by the very small coefficient of asymmetry, which is equal to 0.583 . A slightly different case was observed when analyzing the respondents' monthly income after taxes. The median (1950 EUR) is below the average (3115.36 EUR). This indicates that the monthly income distribution of the respondents in the study is asymmetric. The average monthly income of the respondents is 3115.36 EUR. The unequal distribution may have occurred due to the fact that a greater number of respondents of a higher social status were invited to participate in the survey, and Lithuania's income inequality as of 2019 is one of the largest in Europe [63]. The authors of this study chose to transform the distribution by bringing it closer to the norm. A new variable was created and used to verify whether revenue has a statistically significant effect on relationships between luxury brand perceived value, brand attachment, and purchase intent.

Recently, the main focus of researchers has been on the luxury fashion category [15-17,21,22,64]. An analysis of the scientific literature revealed that the effect of the luxury brand perceived value on brand attachment and purchase intention in the context of consumer vanity can vary depending on the luxury brand chosen and its category. In order to expand the research context and gain new insights, a new research context was chosen, i.e., luxury cars. It has been observed that luxury cars are closely associated with consumer vanity [57], belonging to one of the eight major categories of luxury goods [65]. Respondents were asked to mark which automotive brands they associate with luxury. After creating the most common response profile, named 'Luxury cars', and performing a frequency analysis, it was observed that, of all the options, the car brands that are most often associated with luxury are Bentley (17.9\%), Maserati (17.1\%), and Porsche (15.3\%). Such brands were associated with luxury by $90.6 \%, 86.4 \%$, and $77.8 \%$ of the respondents, respectively. The brands least associated with luxury were Audi (3.4\%), Land Rover (4.6\%), and BMW (5.8\%). These brands were selected by $17.3 \%, 23.4 \%$, and $29.5 \%$ of the respondents, respectively. Respondents were also asked to indicate one luxury brand with which further responses would be associated.

\subsection{Measures}

The online questionnaire was comprised of eight questions and five sections. To measure the constructs, we used previously established and validated scales. The first section contained questions related to luxury car brands that are most relevant to luxury for respondents, and the selection of one luxury car brand with which further questions in the questionnaire would be associated. Then, each respondent was asked whether he or she had purchased a car of the chosen luxury brand. This question was used to determine whether relationships between constructs differ between these two groups of respondents. The second section measured luxury brand perceived value. Vigneron and Johnson's and Berthon et al.'s 7-point Likert-type scales were adopted to capture the luxury brand perceived value, which may be functional, experiential, or symbolic [7-10,38] (Appendix A, Table A1). The third section measured brand attachment and the items were adapted from Park et al. using a 10-point Likert scale [40]. This construct was measured through four items (Appendix A, Table A2). The fourth section measured purchase intention, and Grewal et al.'s 7-point Likert scale, which contains 3 items [66] (Appendix A, Table A3), was used. The fifth section measured consumer vanity, and we used Netemeyer, Burton, and Lichtenstein's 7-point Likert scale [40]. The vanity construct consists of physical concern 
(5 items), a physical view (6 items), achievement concern (5 items), and an achievement view (5 items) (Appendix A, Table A4). Each factor was measured through four items on the 7-point Likert scale (1-'completely disagree'; 7-'completely agree'). The final section contained socio-demographic questions. A pre-test with 20 respondents was performed in order to ensure conceptual equivalence between the initial English questionnaire and the translated questionnaire in Lithuanian.

\section{Results}

\subsection{Exploratory Factor Analysis}

We conducted an exploratory factor analysis (EFA) to evaluate the applicability of scales and to identify the structure of constructs to be researched. Each scale was verified separately using the principal components method of extraction (Verimax rotation). The results of the EFA and the respective Cronbach's alpha values are presented in Table 1.

Table 1. Exploratory Factor Analyses for study constructs.

\begin{tabular}{|c|c|c|c|c|c|c|}
\hline Concept & Factor & No of Items & KMO & $\begin{array}{l}\text { Range of } \\
\text { Factor Loading }\end{array}$ & $\begin{array}{c}\text { Variance } \\
\text { Explained by } \\
\text { Each Factor, \% }\end{array}$ & $\begin{array}{c}\text { Cronbach's } \\
\text { Alpha }\end{array}$ \\
\hline \multirow{3}{*}{$\begin{array}{l}\text { Luxury brand } \\
\text { perceived value } \\
\text { (Cronbach's } \\
\text { alpha }=0.9)\end{array}$} & \multirow{3}{*}{$\begin{array}{l}\text { LBP functional value } \\
\text { LBP experiential } \\
\text { value } \\
\text { LBP symbolic value }\end{array}$} & 3 & \multirow{3}{*}{0.885} & $0.696-0.848$ & 29.21 & 0.815 \\
\hline & & 6 & & $0.670-0.829$ & 21.52 & 0.889 \\
\hline & & 4 & & $0.692-0.823$ & 17.92 & 0.827 \\
\hline Brand attachment & Brand attachment & 4 & 0.635 & $0.764-0.858$ & 69.22 & 0.850 \\
\hline Purchase intention & Purchase intention & 3 & 0.733 & $0.915-0.953$ & 86.19 & 0.920 \\
\hline \multirow{4}{*}{$\begin{array}{l}\text { Consumer vanity } \\
\text { (Cronbach's } \\
\text { alpha }=0.896)\end{array}$} & $\begin{array}{l}\text { Vanity: physical } \\
\text { concern }\end{array}$ & 5 & \multirow{4}{*}{0.880} & $0.572-0.765$ & 19.61 & 0.760 \\
\hline & Vanity: physical view & 6 & & $0.676-0.874$ & 17.997 & 0.899 \\
\hline & $\begin{array}{c}\text { Vanity: achievement } \\
\text { concern }\end{array}$ & 5 & & $0.711-0827$ & 15.89 & 0.873 \\
\hline & $\begin{array}{c}\text { Vanity: achievement } \\
\text { view }\end{array}$ & 5 & & $0.757-0.761$ & 13.14 & 0.915 \\
\hline
\end{tabular}

Bartlett's test of sphericity, $p<0.05$. LBP value-luxury brand perceived value.

After performing the analysis of the structure of conceptual model constructs, we identified factors that would allow for the modification of original variables. It should be noted that the construct of brand attachment was modified as the factor analysis showed only a single factor; thus, in further analysis, brand attachment was analyzed as a onedimensional construct. For this reason, we revised the $\mathrm{H} 2 \mathrm{a}, \mathrm{H} 2 \mathrm{~b}, \mathrm{H} 2 \mathrm{c}$ and $\mathrm{H} 3 \mathrm{a}, \mathrm{H} 3 \mathrm{~b}$, $\mathrm{H} 3 \mathrm{c}, \mathrm{H} 3 \mathrm{~d}, \mathrm{H} 3 \mathrm{e}, \mathrm{H} 3 \mathrm{f}, \mathrm{H} 3 \mathrm{~g}$ hypotheses, which are aimed at the identification of direct effects of brand attachment and its separate dimensions on consumer purchase intention and the evaluation of indirect effects of luxury brand perceived value and its separate dimensions on purchase intention via the mediation of the brand attachment construct and its separate dimensions. Here is a list of the revised hypotheses that were tested during the empirical examination:

Hypothesis 2 ( H2). Brand attachment has a positive effect on purchase intention;

Hypothesis 3a ( H3a). Brand attachment mediates the relationship between luxury brand perceived value and purchase intention in such a way that luxury brand perceived value has a positive effect on brand attachment, which, in turn, has a positive effect on purchase intention;

Hypothesis $3 \mathbf{b}(\mathbf{H} 3 \mathbf{b})$. Brand attachment mediates the relationship between luxury brand perceived functional value and purchase intention in such a way that luxury brand perceived func- 
tional value has a positive effect on brand attachment, which, in turn, has a positive effect on purchase intention;

Hypothesis 3c ( H3c). Brand attachment mediates the relationship between luxury brand perceived experiential value and purchase intention in such a way that luxury brand perceived experiential value has a positive effect on brand attachment, which, in turn, has a positive effect on purchase intention;

Hypothesis 3d ( H3d). Brand attachment mediates the relationship between luxury brand perceived symbolic value and purchase intention in such a way that luxury brand perceived symbolic value has a positive effect on brand attachment, which, in turn, has a positive effect on purchase intention.

\subsection{Descriptive Analysis}

All atypical values (outliers) in the sample were checked before conducting further analysis. For this purpose, the variables were transformed into standardized $\mathrm{z}$ estimates. Values that are considered to be outliers have an absolute $\mathrm{z}$ value greater than 2 , and extreme outliers are values with an absolute $z$ value greater than 3 . The identified extreme outliers were removed from the study sample, and, as such, further analysis was performed with a sample of 505 respondents.

The non-parametric Mann-Whitney U Test was performed to test for differences between two independent groups (in the case of the gender variable and whether the respondent had purchased a car of the chosen luxury brand before ('yes', $N=129$ or 'no', $\mathrm{N}=376$ ) on measures of luxury brand perceived value, brand attachment, purchase intention, and consumer vanity. A Mann-Whitney $U$ Test revealed that there are statistically significant differences in the scores of luxury brand perceived value (overall construct) $(\mathrm{z}=-4.40, p=0.00)$, luxury brand perceived experiential value $(\mathrm{z}=-6.72, p=0.00)$, brand attachment $(\mathrm{z}=-6.34, p=0.00)$, and purchase intention $(\mathrm{z}=-10.87, p=0.00)$ between the two groups of respondents (with respect to whether or not they had purchased the selected luxury car).

A Mann-Whitney U Test also revealed that there are statistically significant differences in the scores of consumer vanity (overall scale) $(z=-3.36, p=0.001)$ regarding the view of physical appearance $(\mathrm{z}=-4.23, p=0.00)$ and the view of personal achievements as facets of vanity $(\mathrm{z}=-2.12, p=0.034)$ of men $(\mathrm{N}=357)$ and women $(\mathrm{N}=148)$. It was identified that gender and the fact that the respondent had purchased a car of the selected brand may affect the manifestation of the analyzed constructs; thus, these variables were used as control variables in the multiple linear regression analysis.

A correlation analysis was performed to check for the existence of statistically significant relationships between the analyzed constructs and respondents' age and income. A statistically significant relationship between respondents' age and the following dimensions was identified: luxury brand perceived value $(r=-0.097, p<0.05)$, purchase intention $(r=-0.112, p<0.05)$, achievement concern $(r=-0.160, p<0.001)$, and achievement view $(r=0.126, p<0.05)$. A statistically significant relationship between respondents' income and the following dimensions was identified: brand attachment $(r=0.149, p=0.001)$, purchase intention $(r=0.170, p<0.001)$, physical concern $(r=-0.113, p<0.05)$, and achievement view $(r=0.331, p<0.001)$. Therefore, these variables were used as control variables in the multiple linear regression analysis.

A further correlation analysis (Table 2 ) revealed that almost all variables are statistically significantly related to each other $(p<0.001$ or $p<0.05)$. All statistically significant relationships are positive with some differences in extent. A statistically significant relationship was not found between the following constructs: perceived functional value and physical concern, perceived experiential value and purchase intention (thus, H1c is not supported), and purchase intention and physical concern as well as physical view $(p>0.05)$. 
Table 2. Means, standard deviations, and intercorrelations among variables.

\begin{tabular}{|c|c|c|c|c|c|c|c|c|c|c|c|}
\hline Variables & 1. & 2. & 3. & 4. & 5. & 6. & 7. & 8. & 9. & 10. & 11. \\
\hline 1. LBP value & 1 & & & & & & & & & & \\
\hline 2. LBP functional value & $0.67^{* *}$ & 1 & & & & & & & & & \\
\hline 3. LBP experiential value & $0.87^{* *}$ & $0.44^{* *}$ & 1 & & & & & & & & \\
\hline 4. LBP symbolic value & $0.83 *$ & $0.49^{* *}$ & $0.54 * *$ & 1 & & & & & & & \\
\hline 5. Brand attachment & $0.27^{* *}$ & $0.22 * *$ & $0.14^{* *}$ & $0.33^{* *}$ & 1 & & & & & & \\
\hline 6. Purchase intention & $0.12 * *$ & $0.24 * *$ & -0.05 & $0.19 * *$ & $0.52 * *$ & 1 & & & & & \\
\hline 7. Consumer vanity & $0.28 * *$ & $0.17 * *$ & $0.22 * *$ & $0.27^{* *}$ & 0.23 ** & $0.13 * *$ & 1 & & & & \\
\hline 8. Physical concern & $0.19 * *$ & 0.06 & $0.17 * *$ & $0.18 * *$ & $0.09 *$ & 0.12 & $0.64 * *$ & 1 & & & \\
\hline 9. Physical view & $0.21 * *$ & $0.14^{* *}$ & $0.16^{* *}$ & $0.19^{* *}$ & $0.15^{* *}$ & 0.07 & $0.70 * *$ & $0.32 * *$ & 1 & & \\
\hline 10. Achievement concern & $0.25^{* *}$ & $0.16^{* *}$ & $0.19 * *$ & $0.26^{* *}$ & $0.22 * *$ & $0.11^{*}$ & $0.76^{* *}$ & $0.38 * *$ & $0.28 * *$ & 1 & \\
\hline 11. Achievement view & $0.17^{* *}$ & $0.15^{* *}$ & $0.12 * *$ & $0.17^{* *}$ & $0.21 * *$ & $0.14 * *$ & $0.68 * *$ & $0.17 * *$ & $0.41^{* *}$ & $0.43 * *$ & 1 \\
\hline $\mathrm{M}$ & 5.23 & 5.77 & 5.24 & 4.81 & 4.83 & 4.39 & 4.15 & 3.92 & 3.89 & 4.28 & 4.56 \\
\hline SD & 1.05 & 1.11 & 1.25 & 1.38 & 2.63 & 1.88 & 0.85 & 1.09 & 1.11 & 1.40 & 1.17 \\
\hline
\end{tabular}

LBP value-luxury brand perceived value, ${ }^{* *} p<0.001{ }^{*} p<0.05$.

\subsection{Hypotheses Testing Results}

Multiple regression analyses were performed to test Hypotheses H1a, H1b, H1d) and H2 (Table 3). Hypothesis H1a, which states that luxury brand perceived value has a positive effect on purchase intention, was confirmed. After accounting for the control variables (age, income, and previous brand purchase experience), the findings show that luxury brand perceived value (overall score) has a positive and significant effect on purchase intention $(\beta=0.188, p<0.000)$. The absence of a statistically significant relationship between luxury brand perceived experiential value and purchase intention denies the correctness of the application of regression models; therefore, Hypothesis H1c (i.e., luxury brand perceived experiential value has positive effect on purchase decision) is not supported. Next, we performed a multiple regression analysis with purchase intention as a dependent variable and the luxury brand perceived functional and symbolic values as independent variables (age, income, and previous purchase experience were included as the control variables). Hypothesis $\mathrm{H} 1 \mathrm{~b}$, which states that luxury brand perceived functional value has a positive effect on purchase decision $(\beta=0.14, p=0.003)$, and Hypothesis H1d, which states that luxury brand perceived symbolic value has a positive effect on purchase intention $(\beta=0.138, p=0.003)$, were confirmed.

Table 3. Multiple regression analyses for testing $\mathrm{H} 1 \mathrm{a}, \mathrm{H} 1 \mathrm{~b}, \mathrm{H} 1 \mathrm{~d}$ and $\mathrm{H} 2$.

\begin{tabular}{|c|c|c|c|c|c|c|c|c|c|}
\hline \multirow{3}{*}{ Independent Variable. } & \multicolumn{9}{|c|}{ Dependent Variable } \\
\hline & \multicolumn{3}{|c|}{ Purchase Intention } & \multicolumn{3}{|c|}{ Purchase Intention } & \multicolumn{3}{|c|}{ Purchase Intention } \\
\hline & $\beta$ & SE & $p$ & $\beta$ & SE & $p$ & $\beta$ & SE & $p$ \\
\hline LBP value & 0.188 & 0.04 & 0.00 & & & & & & \\
\hline LBP functional value & & & & 0.140 & 0.049 & 0.003 & & & \\
\hline LBP symbolic value & & & & 0.138 & 0.047 & 0.003 & & & \\
\hline Brand attachment & & & & & & & 0.381 & 0.04 & 0.000 \\
\hline PBPE ('yes' or 'no') & 0.476 & 0.099 & 0.00 & 0.453 & 0.095 & 0.000 & 0.783 & 0.093 & 0.000 \\
\hline Age & -0.118 & 0.005 & 0.006 & -0.118 & 0.004 & 0.005 & -0.012 & 0.004 & 0.004 \\
\hline Income & 0.113 & 0.053 & 0.009 & 0.112 & 0.053 & 0.009 & 0.101 & 0.05 & 0.042 \\
\hline Model summary & $\mathrm{F}=(4,4$ & $\begin{array}{l}\mathrm{dj}=0.2 \\
=42.0\end{array}$ & $=0.000$ & $\mathrm{R}^{2 \mathrm{adj}}=0$ & $\begin{array}{l}F=(5, \\
=0.00\end{array}$ & $=37.81$ & $\mathrm{~F}=(4,4$ & $\begin{array}{l}\text { dj }=0.3 \\
=65.8\end{array}$ & $=0.000$ \\
\hline
\end{tabular}

LBP value-luxury brand perceived value, PBPE—previous brand purchase experience.

Brand attachment demonstrated a statistically significant and positive effect on purchase intention $(\beta=0.378, p<0.000)$; thus, Hypothesis $\mathrm{H} 2$, which states that brand attachment has a positive effect on purchase intention irrespective of age, income, and the previous purchase of a luxury car, was confirmed. 
Aiming to identify indirect effects of luxury brand perceived value and its separate dimensions on purchase intention when this relationship is possibly mediated by brand attachment, and to test Hypotheses $\mathrm{H} 3 \mathrm{a}, \mathrm{H} 3 \mathrm{~b}, \mathrm{H} 3 \mathrm{c}$ and $\mathrm{H} 3 \mathrm{~d}$, we performed a regressionbased mediation analysis using SPSS PROCESS model No 4 [67]. The obtained results (Table 4) show the existence of a statistically significant effect of luxury brand perceived value on brand attachment (path $a ; \mathrm{B}=0.258, p=0.000$ ) and an effect of brand attachment on purchase intention (path $b ; \mathrm{B}=0.517, p=0.000$ ).

Table 4. Mediation analysis: indirect effect of luxury brand perceived value on purchase intention through brand attachment.

\begin{tabular}{|c|c|c|c|c|c|c|c|c|c|c|c|c|}
\hline \multirow{3}{*}{ Regressor } & \multicolumn{12}{|c|}{ Dependent Variable } \\
\hline & \multicolumn{4}{|c|}{ M: Brand Attachment } & \multicolumn{4}{|c|}{ Y: Purchase Intention (PI) } & \multicolumn{4}{|c|}{ Y: Purchase Intention (PI) } \\
\hline & Path & B & SE & $p$ & Path & B & SE & $p$ & Path & B & SE & $p$ \\
\hline Intercept & $\mathrm{i}_{\mathrm{M}} \rightarrow$ & -1.34 & 0.22 & 0.00 & $i_{Y} \rightarrow$ & 0.239 & 0.21 & 0.25 & $i_{Y} \rightarrow$ & -0.46 & 0.23 & 0.05 \\
\hline X: LBP value & $a \rightarrow$ & 0.258 & 0.04 & 0.00 & $c^{\prime} \rightarrow$ & -0.05 & 0.04 & 0.24 & $c \rightarrow$ & 0.087 & 0.04 & 0.05 \\
\hline M: BA & & - & - & - & $b \rightarrow$ & 0.517 & 0.04 & 0.000 & - & - & - & - \\
\hline $\begin{array}{l}\text { Model } \\
\text { summary }\end{array}$ & \multicolumn{4}{|c|}{$\begin{array}{c}\mathrm{R}^{2}=0.070 ; \mathrm{F}(1 ; 503)=37.905 \\
p=0.000\end{array}$} & \multicolumn{4}{|c|}{$\begin{array}{c}\mathrm{R}^{2}=0.255 ; \mathrm{F}(2 ; 502)=85.897 \\
p=0.000\end{array}$} & \multicolumn{4}{|c|}{$\begin{array}{c}\mathrm{R}^{2}=0.008 ; \mathrm{F}(1 ; 503)=4.035 \\
p=0.045\end{array}$} \\
\hline
\end{tabular}

LBP value-luxury brand perceived value, BA-brand attachment, PI-purchase intention.

The total effect of luxury brand perceived value on purchase intention is statistically significant as well (path $c, \mathrm{~B}=0.087, p=0.045$ ). It was identified that the bias-corrected bootstrap $95 \%$ confidence interval of the indirect effect $\left(a^{*} b\right)$ does not include zero $(\mathrm{B}=0.133$, $\mathrm{LLCI}=0.089$, ULCI $=0.184$ ), allowing for the conclusion that Hypothesis H3a stands.

$\mathrm{H} 3 \mathrm{~b}, \mathrm{H3c}$, and $\mathrm{H} 3 \mathrm{~d}$ were tested using the same PROCESS model No 4. The results of the indirect effect of luxury brand perceived functional value on purchase intention through brand attachment (Hypothesis H3b) are summarized in Table 5 . The path between luxury brand perceived functional value and brand attachment is positive and significant (path $a, \mathrm{~B}=0.212, p=0.000$ ). Similarly, the path between brand attachment and purchase intention is also positive and significant (path $b, \mathrm{~B}=0.481, p=0.000$ ). The analysis shows a statistically significant direct effect of luxury brand perceived functional value on purchase intention (path $c^{\prime} ; \mathrm{B}=0.121, p=0.003$ ). The total effect of luxury brand perceived functional value on purchase intention is statistically significant as well (path $c ; \mathrm{B}=0.224$, $p=0.000)$. Furthermore, the indirect effect of luxury brand perceived functional value on purchase intention through brand attachment is positive and statistically significant as the bias-corrected bootstrapping 95\% confidence interval does not include zero $(B=0.102$, $\mathrm{LLCI}=0.057, \mathrm{ULCI}=0.155)$. Thus, Hypothesis H3b stands.

Table 5. Mediation analysis: indirect effect of luxury brand perceived functional value on purchase intention through brand attachment.

\begin{tabular}{|c|c|c|c|c|c|c|c|c|c|c|c|c|}
\hline \multirow{3}{*}{ Regressor } & \multicolumn{12}{|c|}{ Dependent Variable } \\
\hline & \multicolumn{4}{|c|}{ M: Brand Attachment } & \multicolumn{4}{|c|}{ Y: Purchase Intention (PI) } & \multicolumn{4}{|c|}{ Y: Purchase Intention (PI) } \\
\hline & Path & B & SE & $p$ & Path & B & SE & $p$ & Path & B & SE & $p$ \\
\hline Intercept & $\mathrm{i}_{\mathrm{M}} \rightarrow$ & 0.004 & 0.43 & 0.92 & $i_{Y} \rightarrow$ & -0.006 & 0.04 & 0.878 & $i_{Y} \rightarrow$ & -0.004 & 0.04 & 0.93 \\
\hline$X$ : LBPF value & $a \rightarrow$ & 0.212 & 0.05 & 0.00 & $c^{\prime} \rightarrow$ & -0.121 & 0.04 & 0.003 & $c \rightarrow$ & 0.224 & 0.05 & 0.00 \\
\hline M: BA & & - & - & - & $b \rightarrow$ & 0.481 & 0.04 & 0.000 & - & - & - & - \\
\hline $\begin{array}{c}\text { Model } \\
\text { summary }\end{array}$ & \multicolumn{4}{|c|}{$\begin{array}{c}\mathrm{R}^{2}=0.041 ; \mathrm{F}(1 ; 503)=21.348 \\
p=0.000\end{array}$} & \multicolumn{4}{|c|}{$\begin{array}{c}\mathrm{R}^{2}=0.266 ; \mathrm{F}(2 ; 502)=90.769 \\
p=0.000\end{array}$} & \multicolumn{4}{|c|}{$\begin{array}{c}\mathrm{R}^{2}=0.045 ; \mathrm{F}(1 ; 503)=23.629 \\
p=0.000\end{array}$} \\
\hline
\end{tabular}

Indirect effect: LBPF value $\rightarrow \mathrm{BA} \rightarrow \mathrm{PI}\left(a^{*} b\right)=0.102,95 \%$ Boot CI $(0.057,0.155), 10,000$ bootstrap samples 
The results of the indirect effect of luxury brand perceived experiential value on purchase intention through brand attachment (Hypothesis H3c) are summarized in Table 6. Luxury brand perceived experiential value has a statistically significant positive effect on brand attachment (path $a, \mathrm{~B}=0.145 ; p=0.001$ ), while brand attachment has a statistically significant positive effect on purchase intention (path $b, \mathrm{~B}=0.524 ; p=0.000$ ). Luxury brand perceived experiential value also has a statistically significant direct effect on purchase intention; however, it is a negative one (path $c^{\prime}, \mathrm{B}=-0.140 ; p=0.000$ ). Nevertheless, the total effect of luxury brand perceived experiential value on purchase intention is not statistically significant (path $c, B=-0.064, p=0.157$ ). As expected, luxury brand perceived experiential value has a statistically significant positive effect on purchase intention via brand attachment $\left(a^{*} b, \mathrm{~B}=0.076\right.$; bias-corrected bootstrapping $95 \%$ confidence interval $\mathrm{LLCI}=0.032 ; \mathrm{ULCI}=0.123$ ). Thus, Hypothesis H3c stands.

Table 6. Mediation analysis: indirect effect of luxury brand perceived experiential value on purchase intention through brand attachment.

\begin{tabular}{|c|c|c|c|c|c|c|c|c|c|c|c|c|}
\hline \multirow{3}{*}{ Regressor } & \multicolumn{12}{|c|}{ Dependent Variable } \\
\hline & \multicolumn{4}{|c|}{ M: Brand Attachment } & \multicolumn{4}{|c|}{ Y: Purchase Intention (PI) } & \multicolumn{4}{|c|}{ Y: Purchase Intention (PI) } \\
\hline & Path & B & SE & $p$ & Path & B & SE & $p$ & Path & B & SE & $p$ \\
\hline Intercept & $\mathrm{i}_{\mathrm{M}} \rightarrow$ & 0.008 & 0.04 & 0.86 & $i_{Y} \rightarrow$ & -0.001 & 0.038 & 0.98 & $i_{Y} \rightarrow$ & 0.003 & 0.04 & 0.95 \\
\hline$X:$ LBPE value & $a \rightarrow$ & 0.145 & 0.05 & 0.001 & $c^{\prime} \rightarrow$ & -0.14 & 0.039 & 0.000 & $c \rightarrow$ & -0.06 & 0.05 & 0.16 \\
\hline M: BA & & - & - & - & $b \rightarrow$ & 0.524 & 0.039 & 0.000 & - & - & - & - \\
\hline $\begin{array}{l}\text { Model } \\
\text { summary }\end{array}$ & \multicolumn{4}{|c|}{$\begin{array}{c}\mathrm{R}^{2}=0.070 ; \mathrm{F}(1 ; 503)=37.905 \\
p=0.000\end{array}$} & \multicolumn{4}{|c|}{$\begin{array}{c}\mathrm{R}^{2}=0.255 ; \mathrm{F}(2 ; 502)=85.897 \\
p=0.000\end{array}$} & \multicolumn{4}{|c|}{$\begin{array}{c}\mathrm{R}^{2}=0.008 ; \mathrm{F}(1 ; 503)=4.035 \\
p=0.045\end{array}$} \\
\hline
\end{tabular}

Indirect effect: LBPE value $\rightarrow \mathrm{BA} \rightarrow \mathrm{PI}\left(a^{*} b\right)=0.076,95 \%$ Boot CI $(0.032,0.123), 10,000$ bootstrap samples

LBP value-luxury brand perceived experiential value, BA-brand attachment, PI—purchase intention.

The results of the indirect effect of luxury brand perceived symbolic value on purchase intention via brand attachment are summarized in Table 7. Luxury brand perceived symbolic value has a statistically significant positive effect on brand attachment (path $a$, $\mathrm{B}=0.327 ; p=0.000$ ), while brand attachment has a statistically significant positive effect on purchase intention (path $b, \mathrm{~B}=0.503 ; p=0.000$ ). Moreover, the bias-corrected bootstrapping $95 \%$ confidence interval does not contain zero, supporting the existence of an indirect effect $\left(a^{*} b, \mathrm{~B}=0.164\right.$; bias-corrected bootstrapping $95 \%$ confidence interval LLCI $=0.116$; $\mathrm{ULCI}=0.218)$. Consequently, Hypothesis H3d stands.

Table 7. Mediation analysis: indirect effect of luxury brand perceived symbolic value on purchase intention through brand attachment.

\begin{tabular}{|c|c|c|c|c|c|c|c|c|c|c|c|c|}
\hline \multirow{3}{*}{ Regressor } & \multicolumn{12}{|c|}{ Dependent Variable } \\
\hline & \multicolumn{4}{|c|}{ M: Brand Attachment } & \multicolumn{4}{|c|}{ Y: Purchase Intention (PI) } & \multicolumn{4}{|c|}{ Y: Purchase Intention (PI) } \\
\hline & Path & B & SE & $p$ & Path & B & SE & $p$ & Path & B & SE & $p$ \\
\hline Intercept & $\mathrm{i}_{\mathrm{M}} \rightarrow$ & 0.008 & 0.04 & 0.86 & $i_{Y} \rightarrow$ & -0.003 & 0.038 & 0.94 & $i_{Y} \rightarrow$ & 0.001 & 0.04 & 0.99 \\
\hline X: LBPS value & $a \rightarrow$ & 0.327 & 0.04 & 0.00 & $c^{\prime} \rightarrow$ & 0.004 & 0.041 & 0.92 & $c \rightarrow$ & 0.169 & 0.04 & 0.00 \\
\hline M: BA & & - & - & - & $b \rightarrow$ & 0.503 & 0.041 & 0.000 & - & - & - & - \\
\hline $\begin{array}{l}\text { Model } \\
\text { summary }\end{array}$ & \multicolumn{4}{|c|}{$\begin{array}{c}\mathrm{R}^{2}=0.107 ; \mathrm{F}(1 ; 503)=60.258 \\
p=0.000\end{array}$} & \multicolumn{4}{|c|}{$\begin{array}{c}\mathrm{R}^{2}=0.253 ; \mathrm{F}(2 ; 502)=84.969 \\
p=0.000\end{array}$} & \multicolumn{4}{|c|}{$\begin{array}{c}\mathrm{R}^{2}=0.028 ; \mathrm{F}(1 ; 503)=14.666 \\
p=0.045\end{array}$} \\
\hline
\end{tabular}

Indirect effect: LBPS value $\rightarrow$ BA $\rightarrow$ PI $\left(a^{*} b\right)=0.164,95 \%$ Boot CI $(0.116,0.218), 10,000$ bootstrap samples

LBP value-luxury brand perceived symbolic value, BA-brand attachment, PI-purchase intention.

To test Hypotheses $\mathrm{H} 4$ and $\mathrm{H} 5$, we performed a regression-based moderation analysis using SPSS PROCESS model No 1 . Hypotheses $\mathrm{H} 4$ and H5 were not confirmed to be statistically significant, as no connections were found $(p>0.05)$. 


\section{Discussion}

This study examined the links between luxury brand perceived value, brand attachment, purchase intention, and consumer vanity. The literature review has revealed that these links are not widely investigated but are important to understanding the reasons why consumers buy goods from luxury brands. This study contributes to the literature on luxury brand value and brand attachment in several ways. First, it enriches the literature by investigating luxury brand perceived value as an antecedent of luxury brand attachment. Second, we added to the literature on the indirect effect of luxury brand value on purchase intention through brand attachment as a mediator. Finally, we enriched the literature on exploring the effect of luxury brand perceived value on brand attachment and the effect of luxury brand perceived value on purchase intentions under the boundary condition of consumer vanity.

As expected, our study found that luxury brand perceived value positively affects purchase intention. Worth mentioning is that separate luxury brand perceived value dimensions influence the purchase intention positively, although differently. The findings show that purchase intention is mostly affected by luxury brand perceived functional value. The effect of perceived functional value has also been identified by other researchers [15-17,19]. This confirms that consumers buy luxury brand goods because they believe them to be made with the utmost craftsmanship and be of the highest quality. The factor analysis revealed that the statements 'luxury brand cars are made with extremely high craftsmanship' and 'luxury brand cars are of the best quality' have the highest factor loadings in our study.

The current study's findings may also be attributable to the cultural peculiarities. For example, German consumers place relatively higher importance on luxury brand functional value than consumers in Brazil, France, Hungary, India, Italy, Japan, Slovakia, Spain, and the United States [68]. The geographical proximity of Germany and Lithuania and the relatively low cultural distance may allude to the cross-cultural similarities in consumer preferences. The product category may also explain consumers' functional orientation. Though automobiles are prominent in signalling status, it may also be the case that consumers truly believe in and prioritize the functional value over other dimensions of luxury brand perceived value and consider functional usefulness to be a prerequisite for the other value dimensions to be considered.

However, within our sample, luxury brand perceived experiential value was not related to purchase intention. As anticipated, luxury brand perceived symbolic value had a statistically significant positive effect on purchase intention. According to Tynan et al., these luxury brand perceived value dimensions allow consumers to differentiate between luxury brands, but, in general, consumers only focus on high functional value, which partially explains the obtained results [14].

The results support the hypothesis that brand attachment has a direct positive effect on purchase intention, and this finding is in line with other research $[16,17,20-23]$. Previous studies note that the brand is important to consumers only in cases when they are attached to the brand.

While testing the indirect effect of luxury brand perceived value on purchase intention via brand attachment as the mediator, it was identified that luxury brand perceived value and its separate dimensions have a statistically significant positive indirect effect on purchase intention. The higher the luxury brand perceived value, the higher the brand attachment, which, in turn, strengthens the purchase intention. Our findings reveal that purchase intention (via brand attachment) is most strongly affected by luxury brand perceived symbolic value. This suggests that consumer purchase intention is mostly affected by a brand's ability to convey to the consumer desired success, leadership, and powerrelated values. Such results are in line with the notion that the primary motivation for luxury consumption lies in the symbolic benefit luxury brands are capable of providing [34]. The long-lasting consumer preference for luxury stems from the fundamental human desire for status [69]. Status, thus, is receptive to the meanings consumers ascribe to it. Cur- 
rent market developments show that even pro-environmental behavior and investing in parenting are being exhibited as high-status symbols [29].

Finally, we examined the effect of consumer vanity on the relationship between luxury brand perceived value and purchase intention and between luxury brand perceived value and brand attachment. We found that consumer vanity does not have a statistically significant effect on the mentioned relationships. Contrary to expectations, consumer vanity did not function as a moderator within our sample. These results are not in line with Hung et al.'s and Cheah et al.'s findings, in which a moderating effect of separate consumer vanity dimensions on the relationship between luxury brand perceived value and purchase intention was found $[16,18]$. Our results are in contrast to the findings of research in related domains. For example, [39] found that the relationship between ideal self-congruence (which can be attained through luxury brand value) and brand attachment is conditional and is present only under the condition of low self-esteem (vanity, being a component of narcissism, presumably reflects overcompensation for low self-esteem). Our results are also different from those of [21], which found that the effect of ideal self-congruence on luxury brand attachment is strengthened by self-esteem. The inconsistency in findings points to the need for further research.

\section{Conclusions, Further Directions, and Implications}

In conclusion, luxury brand perceived value is positively related to purchase intention, but the strength of the relationship depends on the separate dimension of perceived value. Furthermore, luxury car brand attachment represents a positive effect on purchase intention among brand-attached consumers. In addition, our research suggests that consumer vanity may moderate the link between luxury brand perceived value and purchase intention, as individuals seeking physical attractiveness and recognition from others are more likely to purchase luxury brands and emphasize that value. However, in the case of Lithuanian consumers, vanity was not found to have a moderating effect on the relationship between the mentioned linkages.

Moreover, the current study has research limitations that could lead to further research directions. Firstly, we used a non-probability sampling and cross-sectional research design, which prevents claims of causation. As such, we cannot present generalizable conclusions about the population. Thus, the development of a causal research design based on the findings of the current research would provide valuable data related to the investigated links among luxury brand perceived value, brand attachment, purchase intention, and consumer vanity.

According to [40], brand attachment is to be analyzed through two dimensions: brand prominence and brand self-connection. However, after the factor analysis, brand attachment was considered to be a one-dimensional construct. According to Park et al.'s recommendations, the four-item measurement scale of brand attachment was used instead of a 10-item scale [40]. Further research could use all 10 items of the brand attachment scale.

Regarding the results for consumer vanity, the standard deviation of the scale was the lowest compared with the scales used to measure other constructs. It is possible that the respondents found the questions too personal and were reluctant to answer truthfully.

In addition, it is likely that consumer vanity (and its dimensions) could have a differential effect on the relationship between the individual dimensions of luxury brand perceived value and brand attachment and between the individual dimensions of luxury brand perceived value and purchase intention. Thus, researchers may also include these links in further research.

Based on Hung et al. and Cheah et al., brand attachment and purchase intention may be affected by both luxury brand perceived value and social factors that could be included in further research $[16,17]$. In addition, as we have only focused on purchase intention in this study, further research could examine consumers' willingness to recommend a brand and pay a price premium [11]. Moreover, it has been found that consumers are willing to purchase counterfeit luxury brand products $[11,21,53,70]$. Finally, a high luxury brand 
perceived value [11], strong brand attachment, and material values [21], which are closely related to achievement vanity $[54,55,71]$, have negative effects on consumer intention to purchase counterfeit products. Further research could compare genuine luxury brand products with counterfeit products.

In addition, this study was conducted in the context of luxury cars, and the research examined focused mainly on luxury fashion brands. Moreover, the developed conceptual model could be tested in other major categories of luxury goods, such as jewellery, cosmetics, wine, hotels, tourism, and private banking [65], as different research results are expected depending on the selected product category $[17,19,72]$.

The findings of this study have important implications for luxury car marketers in Lithuania. The results highlight the significant effect of a luxury brand's perceived social value on purchase intentions, so it would be worthwhile emphasizing the quality, craftmanship, and superiority of the luxury car brand in order to attract new consumers and increase sales. The study also revealed that purchase intention (via brand attachment) is most strongly affected by luxury brand perceived symbolic value. Hence, marketers should emphasize the brand's ability to convey consumer success, leadership, and power in order to retain existing consumers.

Author Contributions: Conceptualization, K.P., B.Š., A.R., and K.K.; methodology, K.P., B.Š., and A.R.; software, K.P., B.Š., and A.R.; validation, K.P., B.Š., and A.R.; formal analysis, K.P., B.Š., and A.R.; investigation, K.P., B.Š., A.R., and K.K.; resources, K.P., B.Š., and A.R.; writing-original draft preparation, K.P., B.Š., A.R., and K.K.; writing—review and editing, K.P., B.Š., A.R., and K.K.; visualization, K.P., B.Š., and A.R. All authors have read and agreed to the published version of the manuscript.

Funding: This research received no external funding.

Institutional Review Board Statement: Not applicable.

Informed Consent Statement: Consent was obtained from all subjects involved in the study.

Data Availability Statement: Not applicable.

Conflicts of Interest: The authors declare no conflict of interest.

\section{Appendix A}

Table A1. Luxury brand perceived value measures

\begin{tabular}{|c|c|c|c|}
\hline Measures Adapted from: & Construct & Items & Scale \\
\hline \multirow{3}{*}{$\begin{array}{l}\text { Vigneron and Johnson and } \\
\text { Berthon et al. }[8,38]\end{array}$} & $\begin{array}{l}\text { Luxury brand perceived } \\
\text { functional value }\end{array}$ & $\begin{array}{l}\text { (Luxury brand) is crafted } \\
\text { (Luxury brand) is luxurious * } \\
\text { (Luxury brand) has the best quality } \\
\text { (Luxury brand) is sophisticated * } \\
\text { (Luxury brand) is superior }\end{array}$ & \multirow{3}{*}{$\begin{array}{l}\text { Strongly disagree } \\
\text { (1)-strongly agree (7) }\end{array}$} \\
\hline & $\begin{array}{l}\text { Luxury brand perceived } \\
\text { experiential value }\end{array}$ & $\begin{array}{l}\text { (Luxury brand) is exclusive } \\
\text { (Luxury brand) is precious * } \\
\text { (Luxury brand) is rare } \\
\text { (Luxury brand) is unique } \\
\text { (Luxury brand) is exquisite } \\
\text { (Luxury brand) is attracting (glamorous) } \\
\text { (Luxury brand) is stunning }\end{array}$ & \\
\hline & $\begin{array}{l}\text { Luxury brand perceived } \\
\text { experiential value }\end{array}$ & $\begin{array}{l}\text { (Luxury brand) is conspicuous * } \\
\text { (Luxury brand) is elitist * } \\
\text { (Luxury brand) is extremely expensive * } \\
\text { (Luxury brand) is for the wealthy * } \\
\text { (Luxury brand) is leading } \\
\text { (Luxury brand) is very powerful } \\
\text { (Luxury brand) is rewarding } \\
\text { (Luxury brand) is successful }\end{array}$ & \\
\hline
\end{tabular}

\footnotetext{
* Items were eliminated due to cross loadings.
} 
Table A2. Brand attachment measures

\begin{tabular}{|c|c|c|c|}
\hline Measures Adapted from: & Construct & Items & Scale \\
\hline Park et al. [40] & Brand attachment & $\begin{array}{l}\text { To what extent are your thoughts and } \\
\text { feelings toward (Luxury brand) often } \\
\text { automatic, coming to mind seemingly } \\
\text { on their own? } \\
\text { To what extent do your thoughts and } \\
\text { feelings toward (Luxury brand) come } \\
\text { to you naturally and instantly? } \\
\text { To what extent is (Luxury brand) part } \\
\text { of you and who you are? } \\
\text { To what extent do you feel personally } \\
\text { connected to the (Luxury brand)? }\end{array}$ & $\begin{array}{c}\text { Not at all } \\
\text { (0)-extremely (10) }\end{array}$ \\
\hline
\end{tabular}

Table A3. Purchase intention measures

\begin{tabular}{|c|c|c|c|}
\hline Measures Adapted from: & Construct & Items & Scale \\
\hline Grewal et al. [66] & Purchase intention & $\begin{array}{l}\text { If I were going to buy a luxury car, } \\
\text { the probability of buying this } \\
\text { (Luxury brand) is } \\
\text { The probability that I would } \\
\text { consider buying this (Luxury } \\
\text { brand) is } \\
\text { The likelihood that I would } \\
\text { purchase this (Luxury brand) is }\end{array}$ & Very low (1)-very high (7) \\
\hline
\end{tabular}

Table A4. Consumer vanity measures

\begin{tabular}{|c|c|c|c|}
\hline Measures Adapted from: & Construct & Items & Scale \\
\hline \multirow{4}{*}{$\begin{array}{l}\text { Netemeyer, Burton, and } \\
\text { Lichtenstein [55] }\end{array}$} & Vanity: physical concern & $\begin{array}{l}\text { The way I look is extremely important } \\
\text { to me. } \\
\text { I am very concerned about my appearance. } \\
\text { I would feel embarrassed if I was around } \\
\text { people and did not look my best. } \\
\text { Looking my best is worth the effort. } \\
\text { It is important that I always look good. }\end{array}$ & \multirow{4}{*}{$\begin{array}{c}\text { Strongly disagree (1)-strongly } \\
\text { agree (7) }\end{array}$} \\
\hline & Vanity: physical view & $\begin{array}{l}\text { People notice how attractive I am. } \\
\text { My looks are very appealing to others. } \\
\text { People are envious of my good looks. } \\
\text { I am a very good-looking individual. } \\
\text { My body is sexually appealing. } \\
\text { I have the type of body that people want } \\
\text { to look at. }\end{array}$ & \\
\hline & Vanity: achievement concern & $\begin{array}{c}\text { Professional achievements are an } \\
\text { obsession with me. } \\
\text { I want others to look up to me because of } \\
\text { my accomplishments. } \\
\text { I am more concerned with professional } \\
\text { success than most people I know. } \\
\text { Achieving greater success than my peers is } \\
\text { important to me. } \\
\text { I want my achievements to be recognized } \\
\text { by others. }\end{array}$ & \\
\hline & Vanity: achievement view & $\begin{array}{c}\text { In a professional sense, I am a very } \\
\text { successful person. } \\
\text { My achievements are highly regarded } \\
\text { by others. } \\
\text { I am an accomplished person. } \\
\text { I am a good example of } \\
\text { professional success. } \\
\text { Others wish they were as successful as me. }\end{array}$ & \\
\hline
\end{tabular}




\section{References}

1. Euromonitor. 2020. Available online: https://www.euromonitor.com/luxury-goods (accessed on 21 April 2021).

2. Statistika. 2020. Available online: https://www.statista.com/outlook/cmo/luxury-goods/lithuania?currency=cad (accessed on 21 April 2021).

3. Roggeveen, A.L.; Sethuraman, R. How the COVID-19 Pandemic May Change the World of Retailing. J. Retail. $2020,96,169-171$. [CrossRef]

4. McKinsey and Company. 2020. Available online: https://www.mckinsey.com/industries/retail/our-insights/a-perspective-forthe-luxury-goods-industry-during-and-after-coronavirus\# (accessed on 21 April 2021).

5. Bain \& Company. 2014. Available online: https://www.bain.com/migration/press-releases/2014/lens-on-the-worldwideluxury-consumer/ (accessed on 21 April 2021).

6. Kapferer, J.N.; Bastien, V. The Luxury Strategy: Break the Rules of Marketing to Build Luxury Brand, 2nd ed.; Kogan Page Publishers: London, UK, 2012.

7. Vigneron, F.; Johnson, L.W. A review and a conceptual framework of prestige-seeking consumer behavior. Acad. Mark. Sci. Rev. 1999, 1, 1-15.

8. Vigneron, F.; Johnson, L.W. Measuring Perceptions of Brand Luxury. Adv. Lux. Brand Manag. 2017, 6, 199-234. [CrossRef]

9. Kapferer, J.-N. Why are we seduced by luxury brands? J. Brand Manag. 1998, 6, 44-49. [CrossRef]

10. Heine, K. The Concept of Luxury Brands_Luxury Brand Management; EMLYON Business School: Ecully, France, 2012.

11. Hennigs, N.; Wiedmann, K.P.; Klarmann, C.; Behrens, S. The complexity of value in the luxury industry: From consumers' individual value perception to luxury consumption. Int. J. Retail Distrib. Manag. 2015, 43, 922-939. [CrossRef]

12. Jain, S.; Khan, M.N. Measuring the impact of beliefs on luxury buying behavior in an emerging market: Empirical evidence from India. J. Fash. Mark. Manag. Int. J. 2017, 21, 341-360. [CrossRef]

13. Wiedmann, K.-P.; Hennigs, N.; Siebels, A. Value-based segmentation of luxury consumption behavior. Psychol. Mark. 2009, 26, 625-651. [CrossRef]

14. Tynan, C.; McKechnie, S.; Chhuon, C. Co-creating value for luxury brands. J. Bus. Res. 2010, 63, 1156-1163. [CrossRef]

15. Jung Choo, H.; Moon, H.; Kim, H.; Yoon, N. Luxury customer value. J. Fash. Mark. Manag. Int. J. 2012, 16, 81-101. [CrossRef]

16. Hung, K.P.; Huiling Chen, A.; Peng, N.; Hackley, C.; Tiwsakul, R.A.; Chou, C.L. Antecedents of luxury brand purchase intention. J. Prod. Brand Manag. 2011, 20, 457-467. [CrossRef]

17. Cheah, I.; Phau, I.; Chong, C.; Shimul, A.S. Antecedents and outcomes of brand prominence on willingness to buy luxury brands. J. Fash. Mark. Manag. Int. J. 2015, 19, 402-415. [CrossRef]

18. Hennigs, N.; Wiedmann, K.P.; Behrens, S.; Klarmann, C. Unleashing the power of luxury: Antecedents of luxury brand perception and effects on luxury brand strength. J. Brand Manag. 2013, 20, 705-715. [CrossRef]

19. Chattalas, M.; Shukla, P. Impact of value perceptions on luxury purchase intentions: A developed market comparison. Lux. Res. J. 2015, 1, 40. [CrossRef]

20. Saeed, R.; Lodhi, R.N.; Mukhtar, A.M.J.; Hussain, S.; Mahmood, Z.; Ahmad, M. Factors affecting consumer purchase decision in clothing industry of Sahiwal, Pakistan. World Appl. Sci. J. 2013, 24, 844-849.

21. Kaufmann, H.R.; Petrovici, D.A.; Gonçalves Filho, C.; Ayres, A. Identifying moderators of brand attachment for driving customer purchase intention of original vs counterfeits of luxury brands. J. Bus. Res. 2016, 69, 5735-5747. [CrossRef]

22. Ku, T.-H.; Lin, T.-L. Effects of luxury brand perceptions on brand attachment and purchase intention: A comparative analysis among consumers in China, Hong Kong and Taiwan. South Afr. J. Bus. Manag. 2018, 49, 9. [CrossRef]

23. Vercueil, L. Investigating the Antecedents and Consequences of Vehicle Buyers' Brand Attachment Behavior. Ph.D. Thesis, North-West University, Kirkland, WA, USA, 2018.

24. Kastanakis, M.N.; Balabanis, G. Between the mass and the class: Antecedents of the "bandwagon" luxury consumption. J. Bus. Res. 2012, 65, 1399-1407. [CrossRef]

25. Cristini, H.; Kauppinen-Räisänen, H.; Barthod-Prothade, M.; Woodside, A. Toward a general theory of luxury: Advancing from workbench definitions and theoretical transformations. J. Bus. Res. 2017, 70, 101-107. [CrossRef]

26. Llamas, R.; Thomsen, T.U. The luxury of igniting change by giving: Transforming yourself while transforming others' lives. J. Bus. Res. 2016, 69, 166-176. [CrossRef]

27. Wiedmann, K.P.; Hennigs, N.; Siebels, A. Measuring consumers' luxury value perception: A cross-cultural framework. Acad. Mark. Sci. Rev. 2007, 7, 1.

28. Gurzki, H.; Woisetschläger, D.M. Mapping the luxury research landscape: A bibliometric citation analysis. J. Bus. Res. 2017, 77, 147-166. [CrossRef]

29. Dubois, D.; Jung, S.; Ordabayeva, N. The psychology of luxury consumption. Curr. Opin. Psychol. 2021, 39, 82-87. [CrossRef]

30. Thomsen, T.U.; Holmqvist, J.; von Wallpach, S.; Hemetsberger, A.; Belk, R.W. Conceptualizing unconventional luxury. J. Bus. Res. 2020, 116, 441-445. [CrossRef]

31. Banister, E.; Roper, S.; Potavanich, T. Consumers' practices of everyday luxury. J. Bus. Res. 2020, 116, 458-466. [CrossRef]

32. Ryan, R.M.; Deci, E.L. Intrinsic and extrinsic motivations: Classic definitions and new directions. Contemp. Educ. Psychol. 2020, 25, 54-67. [CrossRef]

33. Sirgy, M.J. Self-Concept in Consumer Behavior: A Critical Review. J. Consum. Res. 1982, 9, 287-300. [CrossRef] 
34. Abimbola, T.; Trueman, M.; Iglesias, O.; Liu, F.; Li, J.; Mizerski, D.; Soh, H. Self-congruity, brand attitude, and brand loyalty: A study on luxury brands. Eur. J. Mark. 2012, 46, 922-937.

35. Malär, L.; Nyffenegger, B.; Krohmer, H.; Hoyer, W.D. Implementing an intended brand personality: A dyadic perspective. J. Acad. Mark. Sci. 2011, 40, 728-744. [CrossRef]

36. Morhart, F.; Malär, L. Authenticity in luxury branding. In Research Handbook on Luxury Branding; Edward Elgar Publishing: Northampton, MA, USA, 2020; pp. 190-207.

37. Ko, E.; Costello, J.P.; Taylor, C.R. What is a luxury brand? A new definition and review of the literature. J. Bus. Res. 2019, 99, 405-413. [CrossRef]

38. Berthon, P.; Pitt, L.; Parent, M.; Berthon, J.-P. Aesthetics and Ephemerality: Observing and Preserving the Luxury Brand. Calif. Manag. Rev. 2009, 52, 45-66. [CrossRef]

39. Malär, L.; Krohmer, H.; Hoyer, W.D.; Nyffenegger, B. Emotional Brand Attachment and Brand Personality: The Relative Importance of the Actual and the Ideal Self. J. Mark. 2011, 75, 35-52. [CrossRef]

40. Park, C.W.; Macinnis, D.J.; Priester, J.; Eisingerich, A.B.; Iacobucci, D. Brand Attachment and Brand Attitude Strength: Conceptual and Empirical Differentiation of Two Critical Brand Equity Drivers. J. Mark. 2010, 74, 1-17. [CrossRef]

41. Keller, K. Strategic Brand Management: Global Edition; Pearson Higher Education: New York, NY, USA, 2013.

42. Taghipourian, M.J.; Bakhsh, M.M. Brand Attachment on Service Loyalty in Banking Sector. Int. J. Mark. Stud. 2016, 8, 146. [CrossRef]

43. Han, Y.J.; Nunes, J.C.; Drèze, X. Signaling status with luxury goods: The role of brand prominence. J. Mark. 2010, 74, 15-30. [CrossRef]

44. Thai, N.V.; Vuong, D.H.; Ha, N.T.T.; Thinh, N.Q.; Kim, M.H.; Quy, N.L.D. Exploring brand loyalty toward traditional confectioneries in an emerging market. Entrep. Sustain. Issues 2020, 8, 60-72. [CrossRef]

45. Park, C.W.; MacInnis, D.J.; Priester, J. Brand attachment: Constructs, consequences, and causes. Found. Trends Mark. 2008, 1, 191-230. [CrossRef]

46. Porter, M.E. Consumer Behavior, Retailer Power and Market Performance in Consumer Goods Industries. Rev. Econ. Stat. 1974, 56, 419. [CrossRef]

47. Louis, D.; Lombart, C. Impact of brand personality on three major relational consequences (trust, attachment, and commitment to the brand). J. Prod. Brand Manag. 2010, 19, 114-130. [CrossRef]

48. Han, Y.J.; Nunes, J.; Drèze, X. First Impressions: Status Signaling using Brand Prominence; American Psychological Association (APA): Washington, DC, USA, 2009; pp. 15-09.

49. Knight, D.K.; Kim, E.Y. Japanese consumers' need for uniqueness: Effects on brand perceptions and purchase intention. J. Fash. Mark. Manag. Int. J. 2007, 11, 270-280. [CrossRef]

50. Tian, K.T.; Bearden, W.O.; Hunter, G.L. Consumers' Need for Uniqueness: Scale Development and Validation. J. Consum. Res. 2001, 28, 50-66. [CrossRef]

51. Solomon, M.; Russell-Bennett, R.; Previte, J. Consumer Behaviour; Pearson Higher Education AU: Melbourne, Australia, 2012.

52. Liu, Y.; Kou, Y.; Guan, Z.; Hu, J.; Pu, B. Exploring hotel brand attachment: The mediating role of sentimental value. J. Retail. Consum. Serv. 2020, 55, 102143. [CrossRef]

53. Gallarza, M.G.; Gil-Saura, I.; Holbrook, M.B. The value of value: Further excursions on the meaning and role of customer value. J. Consum. Behav. 2011, 10, 179-191. [CrossRef]

54. Jun, S.; Liang, S.; Qiong, W.; Jian, W. The relationship between the willingness of buying counterfeit goods and consumer personality traits. In Proceedings of the 2012 International Conference on Public Management, Kunming, China, 17-19 August 2012; Atlantis Press: Paris, France, 2012; pp. 378-388.

55. Netemeyer, R.G.; Burton, S.; Lichtenstein, D.R. Trait Aspects of Vanity: Measurement and Relevance to Consumer Behavior. J. Consum. Res. 1995, 21, 612. [CrossRef]

56. Durvasula, S.; Lysonski, S. A double-edged sword: Understanding vanity across cultures. J. Consum. Mark. 2008, 25, 230-244. [CrossRef]

57. Wang, P.Z.; Waller, D.S. Measuring consumer vanity: A cross-cultural validation. Psychol. Mark. 2006, 23, 665-687. [CrossRef]

58. Workman, J.E.; Lee, S.-H. Relationships among consumer vanity, gender, brand sensitivity, brand consciousness and private self-consciousness. Int. J. Consum. Stud. 2012, 37, 206-213. [CrossRef]

59. Etikan, I.; Musa, S.A.; Alkassim, R.S. Comparison of Convenience Sampling and Purposive Sampling. Am. J. Theor. Appl. Stat. 2016, 5, 1. [CrossRef]

60. Malhotra, N.K. Marketing Research: An Applied Orientation, 7th ed.; Pearson Education International: Cranbury, NJ, USA, 2004.

61. Shukla, P. The influence of value perceptions on luxury purchase intentions in developed and emerging markets. Int. Mark. Rev. 2012, 29, 574-596. [CrossRef]

62. Li, N.; Robson, A.; Coates, N. Chinese consumers' purchasing: Impact of value and affect. J. Fash. Mark. Manag. Int. J. 2013, 17, 486-508. [CrossRef]

63. OECD Country Profile of Lithuania. 2019. Available online: https:/ / data.oecd.org/lithuania.htm (accessed on 21 April 2021).

64. Faschan, M.; Chailan, C.; Huaman-Ramirez, R. Emerging adults' luxury fashion brand value perceptions: A cross-cultural comparison between Germany and China. J. Glob. Fash. Mark. 2020, 11, 207-231. [CrossRef] 
65. Kapferer, J.N.; Michaut, A. Luxury and sustainability: A common future? The match depends on how consumers define lux-ury. Lux. Res. J. 2015, 1, 3-17. [CrossRef]

66. Grewal, D.; Monroe, K.B.; Krishnan, R. The effects of price-comparison advertising on buyers' perceptions of acquisition value, transaction value, and behavioral intentions. J. Mark. 1998, 62, 46-59.

67. Hayes, A.F. Introduction to Mediation, Moderation, and Conditional Process Analysis: A Regression-Based Approach; Guilford Press: New York, NY, USA, 2017.

68. Hennigs, N.; Wiedmann, K.-P.; Klarmann, C.; Strehlau, S.; Godey, B.; Pederzoli, D.; Neulinger, A.; Dave, K.; Aiello, G.; Donvito, R.; et al. What is the Value of Luxury? A Cross-Cultural Consumer Perspective. Psychol. Mark. 2012, 29, 1018-1034. [CrossRef]

69. Anderson, C.; Hildreth, J.A.D.; Howland, L. Is the desire for status a fundamental human motive? A review of the empirical literature. Psychol. Bull. 2015, 141, 574-601. [CrossRef]

70. Yoo, B.; Lee, S.H. Buy genuine luxury fashion products or counterfeits? Adv. Consum. Res. 2009, 36, $280-286$.

71. Watchravesringkan Tu, K.; Yurchisin, J.; Yan, R.-N. Cross-cultural invariance of consumers' price perception measures. Int. J. Retail. Distrib. Manag. 2008, 36, 759-779. [CrossRef]

72. Sharda, N.; Bhat, A. Role of consumer vanity and the mediating effect of brand consciousness in luxury consumption. J. Prod. Brand Manag. 2019, 28, 800-811. [CrossRef] 